\title{
Multinational cooperation: building capabilities in small air forces
}

European air power is represented by a variety of air forces, each equipped with different capabilities and facing different limitations. Developing the former and making up for the latter requires resources and finances and is not always possible within a national capacity. It may be particularly problematic for smaller air forces, especially with the trend of shrinking defence budgets and increasing costs of the newest technological achievements. This article investigates the idea of multinational cooperation in Europe as a way to make up for these shortfalls and build collective European capabilities. In doing so, it focuses on two states, namely Poland and Sweden as examples of small air forces. By choosing these countries as case studies it also provides an opportunity to investigate the different forms of multinational involvement existing within and outside a major military alliance, namely NATO. The article explores the participation of the Polish and Swedish Air Forces in several multinational initiatives and investigates how such involvement increases (or not) their capabilities.

Keywords: European air power; multinational cooperation; NATO; Poland; small air forces; Sweden.

\section{Introduction}

The main purpose of this article is to investigate how small air forces can build or strengthen their capabilities through multinational cooperation in the post-Cold War period. The end of that conflict brought significant change in the security context in Europe and started a defence and military transformation across the continent. This process should be understood here as a continuous development and integration of concepts, doctrine and capabilities improving the effectiveness and interoperability of military forces (NATO Glossary of Terms and Definitions AAP-06 (English and French), 2014). Anthony King identified two interconnected trends characteristic for that period, namely concentration and transnationalisation of the armed forces (2011). The former is clearly visible in the shrinking defence budgets and downsizing of military forces. However, it does not mean solely abandoning conscription and reducing numbers at the 
expense of the effectiveness of the armed forces. Concentration of the European militaries, as understood by King, also involves growing professionalisation and specialisation of the military units (2011, p. 33). As a result, the European armed forces are more effective, particularly in terms of cost, than their Cold War predecessors and consist of motivated personnel focused on developing their skills. Nevertheless, they are also smaller and subsequently facing capability or capacity limitations. One way to deal with these shortcomings is through multinational cooperation and that is where one could identify the second trend characteristic for the post-Cold War European armed forces. King refers to this trend as the transnationalisation of European militaries (2011, pp. 4044). This, in turn, is understood as increasing interconnectedness and interdependence of different armed forces, often working in such cases under institutionalised command. Of course, King was not the first scholar to come up with the idea of the internationalisation of military forces. Such a concept was observed by other scholars in business organisations (see Hofstede 2001), police forces (see Soeters et al., 1995) and military academies (see Soeters, 1997). This article demonstrates that also European air forces underwent similar transformation becoming both, more concentrated and transnational.

Answering the aforementioned research question: how small air forces can build or strengthen their capabilities through multinational cooperation, the article argues that such cooperation increases capabilities of those involved in a two-fold way. First of all, it proves important for overcoming the small air forces' shortcomings and filling existing gaps with collective resources. Such an option presents a tangible solution to the already strained defence budgets as a shared effort usually comes with a shared financial burden as well. Secondly, developing and maintaining different forms of multinational cooperation between European air forces, especially the small ones, provides 
participating aircrews with invaluable experience and training opportunities enhancing their operational capabilities at the personnel level.

The article adds to the general knowledge on the topic of European security. Focusing on small air forces it aims to address an important gap in the existing literature on the subject of European air power which has been understudied in a two-fold way. Firstly, the general literature on air power focuses predominantly on the US Air Force as the most advanced air force in the world (see, for example, Lambeth 2000, 2005, Olsen 2011, 2017, van Creveld 2011). Secondly, when European air forces are given attention such studies are dominated by the examples of the most powerful ones, for example the British, French or German Air Force (for example, Anrig 2011b, Hayward 2009, Olsen 2014). Such an approach leaves the smaller air forces out and, as such, does not allow for a comprehensive understanding of the subject of European air power. Therefore, the major contribution of this article is to address the gap in the literature of the subject. Furthermore, it may provide an encouragement for other researchers to pursue further studies on the capabilities and limitations of small European air forces and their involvement in multinational cooperation.

In order to answer the aforementioned research question, the article uses the Polish and Swedish Air Forces as case studies. These were chosen for several reasons. Firstly, both Polish and Swedish Air Forces represent small European air force. Next section will explain in more detail how they fit into this classification. Secondly, as the article focuses on the post-Cold War period, the chosen case studies differ in the geostrategic situation both countries found themselves in the early 1990s. Poland then, as a former Warsaw Pact member, was aspiring to join the Western structures of the EU and NATO, while Sweden coming from a position of neutrality was willing to join the EU and maintain its non-allied status with NATO. At the same time, the Polish and 
Swedish cases demonstrate similarity in a way both Air Forces underwent transformation after the end of the Cold War what influenced their operational capability. Finally, cases of the Polish and Swedish Air Forces are very much understudied. The author encountered a small number of research studies of the subject out of which only a few discuss it in depth and provide a wider perspective (for example Anrig 2011a, 2011b; Bydén 2014). Therefore, using the Polish and Swedish Air Forces as case studies provides a comprehensive view on the small European air forces and their involvement in multinational cooperation in the post-Cold War period as well as contributes to a more detailed knowledge on the case studies in particular.

To investigate the subject of small European air forces and their involvement in multinational cooperation, the article uses qualitative analysis of existing secondary literature and web-based materials: news media and think-tanks such as RAND Corporation, the Royal United Services Institute - RUSI and the Casimir Pulaski Foundation. It focuses on concepts drawn from the abovementioned sources, namely the idea of post-Cold War concentration and transnationalisation of European militaries (King 2011), and uses thematic analysis (Attride-Stirling 2001, King 2004, Nowell et al. 2017) to study the subject of small European air forces, as well as the Polish and Swedish cases in particular. The article also refers to five semi-structured interviews which were conducted with officers at the Polish and Swedish Air Forces, as well as academics (both of military and civilian background) employed at the Swedish Defence University, the Swedish Defence Research Agency and the then National Defence University in Warsaw (now War Studies University). The information gathered during the interviews was used in the article to fill any gaps remaining after the analysis of the secondary literature and to corroborate findings. 
To start with, the article focuses on defining the term 'small air force' as well as explaining how the Polish and Swedish Air Forces fit within this categorisation. The article then investigates the term of military concentration, the first trend identified by King. This section starts with a discussion of the situation in which the named Air Forces found themselves after the Cold War. This is done in order to investigate the implications that the post-Cold War period had on the current state of European air power. Subsequently, the article examines the second trend - transnationalisation. In this section, several chosen initiatives are reviewed which involved the multinational cooperation of the aforementioned Air Forces. Finally, the article concludes with a few points on how the discussed initiatives affect the capabilities of Polish and Swedish Air Forces signalling some of the risks associated with that type of multinational cooperation.

\section{Small air forces}

The term - 'small air force' is a debatable one and could be looked at from different perspectives: the actual size or capabilities of the air force in question. The author did not come across many research studies of the subject of small air forces however it could be argued that the latter approach is more widespread in the available literature. For example, according to S. A. Mackenzie, calling an air force small would be applicable to 'one that, for some fundamental reason, such as economic, geographic, political or social, will have chosen not to conduct some element or part of the complete air power spectrum' (1994, p. 1). Such an approach clearly indicates here that the actual size of the air force, the number of aircraft it flies or the number of active personnel, does not affect the classification in any way. It is the capabilities that matter and that will ultimately enable an air force to perform effectively (or not) within all four main air power roles; control of the air, intelligence, surveillance and reconnaissance (ISR), attack and air mobility. 
A similar viewpoint is presented by Sanu Kainikara, who also provides a much more precise classification of world air forces. He derives it from Alan Stephens' statement that the air powers existent today fall in one of two categories: first, the US Air Force, and second, the rest of the world air force (1999, p. 7). Following on from this point, Kainikara identified three categories of non-US air forces - large, small and niche, which differ from one another by the scope of their capabilities, ability to pursue operations independently and the existence of indigenous industry supporting the national efforts (2011). Therefore, according to this classification, small air forces possess capabilities to undertake the full spectrum of air power roles but in a limited capacity and within a limited timeframe (Kainikara 2011, pp. 75-76). In other words, they do not have enough resources to independently operate at the required level for a long time. However, at the same time, these smaller air forces are a desired ally who can bring their own capabilities and perform them within a coalition led by a larger air power.

Both, the Polish and Swedish Air Forces fit into that category. They possess the full spectrum of capabilities allowing them to perform within each of the four fundamental air power roles - control of the air; ISR; attack and air mobility. However, due to limited capacity, they are not able to perform these roles independently on a large scale and for an extended period of time, whether operating from and within their homeland territory or as a part of an expeditionary mission. Figure 1. illustrates the type and number of aircraft currently possessed by the Polish and Swedish Air Forces. It clearly shows that they have a wide spectrum of capabilities within all four air power roles but are limited by numbers.

Looking at that graph, one could argue that the Polish Air Force should not be categorised as a small air force but rather a niche air force because it does not possess any ISR capability (labelled here as special mission), such as an airborne early warning 
aircraft. However, it must be noted that this particular area is currently under development. On $1^{\text {st }}$ January 2016 , the country officially opened the $12^{\text {th }}$ Unmanned Aerial Vehicle (UAV) Base, the first of its kind. Currently, it operates small UAVs used mostly by the Land Forces, however, the plans involve equipping the Base with shortand medium-range as well as Medium Altitude Long Endurance - MALE aircraft (Górka 2016). These will also add to the country's air recognition capability. Therefore, with that in mind, one could categorise the Polish Air Force as a small air force.

Finally, both Poland and Sweden, possess an industrial capacity supporting their national air power. National procurement capacity is the third and final factor considered by Kainikara in his classification of the world's air forces. In the case of the Swedish Air Force, the example is quite obvious. Globally known Saab develops a number of different solutions for the Air Force, for example Gripen fighter systems, airborne surveillance Erieye or GlobalEye systems or various unmanned aerial platforms supporting also the Army and Navy (Saab). Also, Poland still has some industrial capacity, for example, PZL Mielec, now part of Sikorsky Aircraft Corporation, or PZL Świdnik, now part of Leonardo-Finmeccanica's Helicopter Division. These are producing their own systems such as M-28 Bryza transportation aircraft, multirole helicopters as well as participating in the production of Black Hawk helicopters (PZL Mielec 2009, PZL Świdnik 2010). Therefore, it may be argued that as both countries possess the full spectrum of capabilities in a limited capacity and have industry supporting the national air forces, both Swedish and Polish Air Force can be called small air forces.

\section{Military concentration - Polish and Swedish Air Forces after 1991}

The transformation of the security environment after 1991 presented certain challenges for the involved countries. For Poland, a former Warsaw Pact member, it involved a 
complete re-direction of the political course. Changing the country's focus from Eastern to Western Europe and joining the structures of NATO and the EU was perceived as the main strategic objective (Łastawski 2011, pp. 20-22). Similarly, significant change can be observed in Swedish strategic thinking in the post-Cold War years shifting from national defence and armed neutrality to international crisis and conflict management (Archer 2014, p. 100). According to Magnus Petersson, through the active participation of the Swedish Armed Forces in expeditionary operations the overall multinational cooperation and solidarity should be strengthened and, as a result, Sweden can rely on the help of other countries as and when required even though the country is not part of a military alliance, such as NATO (2011, p. 709). Therefore, despite its non-alignment policy, Sweden, similarly to Poland, perceives NATO, EU and UN as the guarantors of national security.

The new, post-Cold War situation was influential on the state of the Polish and Swedish militaries and more specifically their Air Forces. The process they both underwent reflects the criteria identified by King as characteristic for the post-Cold War concentration of European military forces, namely reduction in size, structural and organisational changes as well as professionalisation (King 2011, pp. 32-40).

As already mentioned in the introduction, the post-1990 period was characterised by a drop in military expenditure in Europe and the situation looked similar in both Poland and Sweden. According to the Stockholm International Peace Research Institute, the military expenditure dropped from 2.6\% of the GDP in 1990 to $2.0 \%$ in 2017 in Poland, and $2.6 \%$ to $1.0 \%$ in Sweden (SIPRI 2018).

The reduction in defence spending falls in line with a downsizing of the Armed Forces. Figure 2. illustrates the process for the Polish and Swedish militaries. According to the data shown, Polish Armed Forces were cut from 312,800 personnel in 1990 to 
99,300 in 2015. A similar decrease was also noted in Sweden where the manpower number was reduced from 64,800 in 1990 to 15,300 in 2015. Considering that Sweden could mobilise an army of almost 800,000 men during the Cold War period, according to John Joel Andersson (2007, p. 139), this reduction in personnel represents quite a significant change.

The situation of the Polish and Swedish Air Forces at that time clearly reflected the general trend. As one can observe from Figure 3., the Air Force in Poland recorded a dramatic cut in military personnel. Active personnel dropped by more than one third from 86,200 in 1990 to 16,600 in 2015. During that period, the Swedish Air Force noted a decrease of 4700 officers, from 8000 men in 1990 to 3300 in 2015.

Shrinking defence budgets and downsizing of the armed forces led to certain organisational and structural changes within both the Polish and Swedish Air Forces reflecting the process of military concentration. The organisational changes within the Polish Air Force started as early as 1990. At that time, the Air Force (Wojska Lotnicze) and the Country Air Defence Force (Wojska Obrony Powietrznej Kraju) were combined into one and have since existed as the Air Force and the Counter-Air Defence Forces (Wojska Lotnicze i Obrony Powietrznej). The latter was then re-named as the Polish Air Force (Siły Powietrzne) in 2004. The inner structure of the Polish Air Force underwent changes too, starting in the late 1990s, by disassembling two regiments and superseding them with two squadrons (Ciastoń et al. 2014, p. 54).

Similar to Poland, the structure of the Swedish Air Forces also changed. In 1990, the Service was organised into 12 Wings, which were also the main air bases. ${ }^{1}$ After the re-organisation, the number significantly dropped and the Swedish Air Force remained with only four operational air bases. ${ }^{2}$ Interestingly, the decision on which of the Swedish air bases should be closed was not, as one would expect, based on their strategic 
importance for national defence. Instead, the main focus was based upon the question 'how many jobs will be lost if that particular air base closes?'?

The downsizing of the Polish and Swedish Air Forces in the post-Cold War period did not only mean reducing the number of active personnel but also the number of aircraft. According to Barre R. Seguin, the number of aircraft in the Polish Air Force dropped from 800 aircraft in 1990 to 300 eight years later and was targeted at 100 in 2002 (2007, p. 6). However, the diminishing inventory was not the only problem. One should remember that, as a former Warsaw Pact member, the majority of aircraft in Poland were either built in the former Soviet Union or constructed under their licence (Dyčka and Mareš 2012, pp. 535 and 538). As a result, most of the Polish Air Force fleet required substantial modernisation. For example, out of the four types of fighters Poland possessed, MiG-21, MiG-23, MiG-29 and Su-22, only the latter two presented any modern combat capability in the post-Cold War period. In order to modernise the Polish Air Force, MiG-21s and MiG-23s, were withdrawn from service by 2004. In return, the fighter fleet was supplied with additional $22 \mathrm{MiG}-29$ s bought from Germany in 2003. In the period between 2006 and 2008, a total of 48 F-16 Block 52+ were delivered as well as 17 CASA C-295M transportation aircraft during 2003-2013 (Średnicki 2015, pp. 1115). As previously mentioned, another significant step was also the opening of the $12^{\text {th }}$ UAV Base on $1^{\text {st }}$ January 2016.

The process of downsizing the Swedish Air Force begun much earlier, in the 1960s, and continued during the following 30 years during which the number of combat aircraft in its inventory dropped from approximately 800 to 400 (Bitzinger 1991, pp. 1315). The Swedish fleet also underwent modernisation which involved replacing Viggen aircraft with JAS-39 Gripen, introducing more advanced types of munitions as well as upgrading command, control, communications and intelligence system (Bitzinger 1991, 
pp. 37-45). This process also focused on improving the aforementioned interoperability between Sweden and NATO member states and their military forces. However, as already mentioned, the transition was challenging and at some points raised a lot of criticism. These adjustments were not always straightforward or easy. For example, switching from the Swedish communication system, Erieye, to NATO LINK16 sparked a lot of discussion and discontent as the Swedish system was far more advanced. ${ }^{4}$ Therefore, using the NATO system was perceived as a step backwards.

Interestingly, it could be argued that some of the decisions made on the modernisation of both, Polish and Swedish Air Forces were to a large extent based on political reasons. For example, when choosing a fighter to boost its fleet, Poland opted for F-16s. Choosing an American fighter rather than Swedish Jas-39 Gripen or French Dassault Mirage 2000-5 Mk II, which were also considered in the process, highlighted the country's desire to maintain close relations with the US and strengthened the reorientation of their political course from East to West (Seguin 2007, pp. 25-26). Similarly, when Sweden decided to replace its Viggens with Gripens rather than, for example, F-16s, which were also taken into consideration at the time, this was very much a political decision. Certainly, continuing reliance on the domestic industry could be perceived as vital for technological development but also as a way to maintain national prestige (Bitzinger 1991, p. 47). Introducing Gripen aircraft into national service was an important factor in maintaining the perception that Sweden was self-sufficient and therefore strengthened its position as a neutral state. The influence of politics could also be seen in other areas of change within the Swedish Air Force. For example, the reason why the Viggen, as well as the early version of the Gripen, aircraft did not possess any AAR capability was also political. It was based on an assumption that if they did, then it could imply that Swedish fighters are able to reach Moscow, which in return could 
provoke the Soviet Union to attack. ${ }^{5}$ Therefore, after the re-organisation and modernisation that took place within the Swedish Air Force (and after the political and strategic context within the region changed) air-to air refuelling was another skill that Swedish aircrews had to learn.

Finally, in the course of the process of concentration, both Swedish and Polish Air Forces underwent professionalisation. That was reflected in creating all-voluntary military forces in both countries. According to Karl Haltiner, the tendency to abolish conscription and introduce professional, voluntary service increases with the growing complexity of the military equipment (2006, p. 373). Considering that air power is completely reliant on equipment and using more advanced solutions and systems, it would require personnel willing to serve on a long-term basis and commit to permanent training. Therefore, moving away from conscription should not come as surprise and happened in Poland and Sweden, respectively in 2009 (Ciastoń et al. 2014, p.11) and 2010 (Archer 2014, p. 100). However, following the growing public support ${ }^{6}$, difficulties to recruit enough military personnel and growing tensions in the Eastern Europe due to the increased Russian activity, Sweden decided to re-activate conscription from $1^{\text {st }}$ of January 2018 (Government Offices of Sweden 2017, Oltermann 2017).

The above section provided a brief overview on the post-Cold War concentration of Polish and Swedish Air Forces. It identified similar processes they underwent such as downsizing, re-organisation and professionalisation characteristic for the aforementioned trend. Next section will look at the process of transnationalisation of the mentioned Air Forces exploring their involvement in various multinational initiatives as a way to improve their operational capabilities. 


\section{Military transnationalisation - multinational cooperation initiatives}

The previous section discussed the concentration of European air forces, focusing on downsizing, re-organisaton, modernisation and professionalisation of the Polish and Swedish Air Forces. Concentration of the military forces, as mentioned at the very beginning, is one characteristic of the post-Cold War transformation of European militaries. The other characteristic is their transnationalisation understood here as increased interdependence and interoperability. There are various opportunities for developing such cooperation among European air forces taking place within the frameworks of NATO the EU and outside of these structures however the scope of this article does not allow for a detailed discussion of all of these. Instead, it focuses on only a few examples where Polish and Swedish Air Forces participate relating to the three areas which demonstrate the biggest shortcomings for European air power - namely ISR, air transport (AT) and air-to-air refuelling (AAR). These were identified as major gaps in the capabilities of European air power during its involvement in conflicts in Bosnia, Kosovo and Libya. These operations revealed high reliance of European air forces on the equipment provided by the US. The major limitation here was the low capacity of resources such as precision munitions and their delivery systems, AT, ISR or AAR (King 2005, p. 329, Quintana et al. 2014, p. 6). For example, in the operation Unified Protector in Libya, $80 \%$ of the total ISR and AAR missions flown were performed by the US. In addition, $50 \%$ of all available AAR aircraft were deployed from the US Air Force (Quintana et al. 2014, p. 6). These limitations are even more evident in the case of small air forces. In reference to Figure 1., both Poland and Sweden, have quite small AT and ISR capabilities, while AAR is practically non-existent. In an attempt to make up for these shortcomings both Air Forces participate in initiatives giving them access to, firstly, 
shared resources and, secondly, to training on a much wider scale than available in home bases.

\section{Shared resources}

In this section, the article focuses on multinational initiatives which give the participating nations an opportunity to boost or develop certain capabilities by pooling and sharing resources. The examples used here for the Polish and Swedish Air Forces involve the NATO Airborne Early Warning system, Alliance Ground Surveillance programme, Strategic Airlift Interim Solution, Strategic Airlift Capability and Air Transport, Air-toAir Refuelling and other Exchange of Services arrangements. These were chosen as aimed at improving the air surveillance, airlift and air-to-air refuelling capabilities among participating nations identified as the major limitations of European air power. As previously mentioned, the way in which the initiatives work is based on maintaining pooled and shared resources in order to make up for the aforementioned limitations of small air forces which, in the case of Polish and Swedish Air Forces, are quite significant.

Referring back to Figure 1. introduced at the beginning of the article which illustrates the number and type of aircraft possessed by both air forces, there are only 45 transportation aircraft in the Polish Air Force inventory. For Sweden, that number is nine times smaller, as the country only has five aircraft of that type. With regards to air surveillance capability, the numbers look even worse. As previously mentioned, the data used for Figure 1. labels the ISR type of aircraft as 'special mission' and as such, the Swedish Air Force has only five of these in their inventory. In the Polish Air Force, this number drops to zero. The situation looks very similar for AAR capability. According to the data provided, there is merely one tanker aircraft available for use in the Swedish Air Force and none for the Polish Air Force. 
These significant shortcomings in both Air Forces, and small air forces in general, could be overcome by using collective resources offered by the multinational initiatives. In addition, such a solution could definitely be regarded as cost-effective since the collective programmes discussed below also allow the participating nations to share the costs of building and strengthening their capabilities. Finally, the multinational initiatives may offer a valid interim solution for a small air force for building their national capabilities.

An example of such an interim solution is the Alliance Ground Surveillance AGS project. As mentioned, the Polish Air Force does not possess any ISR capability. The first Polish UAV base was opened in January 2016 and, at the moment, is operating only small platforms for the use of the Army. Until it becomes fully operational and starts providing air surveillance for the Air Force as well, the gap in capability can be filled with a collective effort - in this case the AGS initiative. ${ }^{7}$ The programme gathers 15 NATO members (including the US) ${ }^{8}$ who are jointly committed to acquire a set of five Global Hawk UAVs with complementing ground command and control systems allowing for the provision of a persistent surveillance from high-altitudes (NATO 2018). Despite being acquired and maintained by 15 nations, it was agreed that the whole system will be available for all 29 NATO members. The first NATO Global Hawk is expected to be available for AGS by the end of 2019 (NATO 2018). Poland has been participating in the initiative between 2004 and 2014. Within this timeframe, there was a five-year gap because, due to financial reasons, it decided to withdraw from AGS on $1^{\text {st }}$ April 2009 (Hołdanowicz 2009). It is likely that this decision was also generated by a reluctance amongst the initiative's members to locate the main AGS base in Powidz in Poland. Instead, the Italian site at Sigonella was chosen as the initiative's main operating base. ${ }^{9}$ 
AGS is not the only ISR-focused multinational initiative that the Polish Air Force is involved in. Another, is the NATO Airborne Early Warning - NAEW system in which Poland has participated since 2006 (Wróbel 2016). The initiative itself is much older and dates back to 1982 which, given its longevity, can definitely be considered one of the most successful multinational collaborative projects in NATO. Currently, NAEW is formed of two components (see NAPMA). One involves 17 Boeing E-3A Airborne Warning and Command System - AWACS aircraft based in Geilenkirchen in Germany. The fleet is maintained by a coalition of 17 NATO members (Poland included). ${ }^{10}$ The other component consists of seven UK-based Boeing E-3D Sentry aircraft manned solely by the Royal Air Force. Poland uses the NAEW system, above all, for gathering accurate data which can easily be used in case of conflict or any other emergency. Moreover, NATO AWACS also supports the Polish Air Force during various mass-scale events such as, for example, the visit of Pope Benedict XVI in 2006, the European Football Championship in 2012 and the Warsaw NATO Summit in 2016 (Ministry of National Defence 2016). Finally, the system is also used to provide necessary airborne surveillance in support of the Polish Air Force rotations in Baltic Air Policing missions (Wróbel 2016).

Sweden does not participate in either the AGS or NAEW initiative. The Swedish Air Force operates three Saab 340 Erieye aircraft which are the Swedish versions of an airborne early warning system and two of the American Gulfstream IV SIGINT aircraft (Flight International 2017, p. 15). The Swedish Air Force, however, is actively involved in the NATO airlift-focused initiatives. As previously mentioned, air transport is one of the major shortcomings of European air power and is an even greater burden for the small air forces. It is also a crucial capability when it comes to performing any kind of an air operation. 
This article discusses two examples of NATO initiatives which were established to fill the strategic airlift gap and which both, Polish and Swedish Air Forces participate in. These are the Strategic Airlift Interim Solution - SALIS, and Strategic Airlift Capability - SAC, created respectively in 2005 and 2008. Although the initiatives complement each other they are separate projects and there are some differences between them. For example, in SAC, there are 12 participating nations in total ${ }^{11}, 10$ of which are NATO members and 2, namely Sweden and Finland, are Partnership for Peace - PfP, states. SALIS, on the other hand is formed of 14 countries -12 NATO members and 2 PfP nations. ${ }^{12}$ As mentioned, both initiatives were started to address the airlift capability shortages, however, SALIS begun as an interim solution which was supposed to last only until the introduction of the Airbus A400M Atlas aircraft into service. Therefore, initially, it was supposed to operate for three years but the project was gradually extended and currently it may continue until 2019 (Sabak 2017). SAC, on the other hand, was established as a permanent programme in order to support the defence or logistical needs of the participating nations as well as the commitments they may have towards NATO, EU, UN or humanitarian operations (SACc).

Finally, both initiatives also differ in terms of the type of aircraft they are using. SALIS members charter six Antonov An-124-100 aircraft from two airline companies the Russian Volga-Dnepr and Ukrainian Antonov, formerly known as the joint venture Ruslan International Ltd (Müller 2016; Quintana et al. 2014, p. 14). In 2014, the initiative's fleet was contracted for a minimum of 2450 flight hours and, after 2016, 60\% of that is being delivered by the Russian airline and the remaining $40 \%$ by the Ukrainian airline (NATO 2015; Sabak 2017). SALIS initiative is a good example of increasing transnationalisation of European air forces in a two-fold way. Firstly, and similarly to SAC, NAEW or AGS, it demonstrates the process of interconnectedness between 
participating air forces through sharing resources. Secondly, it also illustrates increasing interdependencies and potential risks attached to them. Russian-Ukrainian conflict and the growing tensions between Russia and NATO influenced the decision of the Russian Volga-Dnepr to withdraw their participation from the initiative with the end of 2018 (Air Cargo News 2018). That will leave SALIS members with less than a half of the already available AT fleet.

SAC operates via Heavy Airlift Wing - HAW, located at the Pápa Air Base in Hungary. The fleet is formed of three Boeing C-17 Globemaster aircraft acquired and maintained by the programme's members (SACa). As such, the initiative does not rely on third parties providing the required resources. Therefore, it is less susceptible for disruptions similar to those experienced by SALIS participants like a sudden shortage of available aircraft unless one of the participants decides to withdraw their contribution. That would increase the financial burden put on the remaining members but the shared fleet would remain intact.

Both, fleets are being used by Polish and Swedish Air Forces in an attempt to make up for their limitations. As such, SALIS was used by Poland for delivering helicopters and armoured vehicles to Afghanistan during the country's involvement in the ISAF mission (Sabak 2017). Similarly, the SAC initiative was used by both Poland and Sweden to support their airlift needs when deployed to Afghanistan. In fact, Sweden initiated the first mission performed by the HAW for ISAF. It took place in September 2009 and involved transporting cargo from the Swedish Karlsborg Air Base to Afghan Mazar-e-Sharif (SACb). Both Sweden and Poland, were also part of the first HAW mission performed in support of ISAF without any American involvement. Among the seven crew members on that flight were three Swedish and one Polish officer (SACb). Military operations are not the only occasion where initiatives such as SALIS or SAC 
may be used. For example, when the Presidential Tupolev crashed in Smolensk in April 2010 with 89 passengers and seven crew members on board, the Polish Air Force did not have the capacity to transport the bodies of all the 96 victims back home. In this instance, Poland used a C-17 from the SAC fleet to fill that gap. ${ }^{13}$

The last example of a multinational collaborative initiative discussed in this section is the ATARES arrangement, addressing both the airlift and air-to-air refuelling gap within European air power. The acronym stands for Air Transport, Air-to-Air Refuelling and other Exchange of Services and the project is based on the idea of pooling and sharing resources similar to AGS, NAEW, SAC and SALIS. The ATARES initiative was established by the Movement Coordination Centre Europe - MCCE and as such is being pursued outside of the NATO structure which is a key point of distinction from the other four initiatives.

Poland and Sweden are both members of the MCCE - Poland since 2008 and Sweden since 2007 as one of the Centre's founding members. ${ }^{14}$ The ATARES initiative is an example of an arrangement where participating European air forces benefit from building or strengthening their capabilities through compensating for used refuelling services with air transport and vice versa. The amount of airlift provided is calculated according to an Equivalent Flying Hour (EFG) unit which was agreed among the participants as one flying hour for a Lockheed C-130 Hercules and Transall C-160 ${ }^{15}$ (Quintana et al. 2014, p. 11). It is worth noting that the flying hours, regardless of number, must be returned to the ATARES initiative and not to the particular nation which provided the services, for example, air tankers in the first instance (MCCE). Such an arrangement highlights the collaborative nature of the project. It is also a perfect illustration of the aforementioned concept of transnationalisation of European militaries. It increases the effectiveness of sharing AT and AAR resources and the participating states use ATARES 
in various ways. For example, Poland does not possess any refuelling capability and so the Polish Air Force utilises the programme as an opportunity for their personnel to develop and train in that particular skill. ${ }^{16}$ On the other hand, Sweden which has a very small AAR fleet, actively participates in the project making their limited resources available where needed. For example, when MCCE was supporting the Arctic Challenge Exercise in 2017 with the AAR services, a Swedish air tanker was among the aircraft provided (MCCE 2017).

\section{Collective training arrangements}

The previous section focused on building or strengthening certain air power capabilities, such as ISR, AT and AAR through pooling and sharing resources. However, access to a specific type of aircraft is not the only way in which small air forces can benefit from multinational collaborative initiatives. By working with other nations and taking part in different forms of cooperation, the personnel of participating air forces gains invaluable experience - often in areas not available on a national level. This experience is an integral part of any multinational initiative, including those already discussed. However, there are also programmes established specifically for training purposes including the learning of new skills as well as consolidating existing ones. Examples of such will be discussed in the following section and include Cross Border Training, European Air Transport Training and the European Advanced Airlift Tactics Training Course.

Similar to the pooling and sharing of projects, the training arrangements are also a cost-effective solution for small air forces to raise the qualification standards of their military personnel. As with acquiring and maintaining a shared fleet, it is much cheaper to organise a large exercise using several nations' resources instead of only one. A very good example here is Sweden and its involvement in different forms of cooperation in 
the region such as the previously mentioned Cross Border Training (CBT).

The project itself is part of a larger initiative, Nordic Defence Cooperation NORDEFCO, which includes Finland, Norway, Sweden, Denmark and Iceland. CBT was established in 2009 as a short-term agreement allowing the Swedish, Finnish and Norwegian Air Forces use of their common air space for training purposes (Dahl 2014, p. 8). One of the certain benefits that comes with such an arrangement is the reduction in bureaucracy. On a weekly basis the three Air Forces fly from their home bases in Bodø (Norway), Luleå (Sweden) and Rovaniemi (Finland) in order to train together for combat missions without asking for special permission from their superiors to use each other's air space every single time. ${ }^{17}$ Another obvious benefit coming from a cooperation such as CBT is the cost-effectiveness as previously mentioned. For example, Sweden can rarely afford to spare a substantial number of Gripen fighters to conduct a training mission but if the country cooperates with Norway and Finland and each delegates 6 aircraft then they have a small fleet of 18 fighters enabling them to conduct a complicated exercise on a scale they could not organise or afford on their own. ${ }^{18}$

Therefore, the more frequently small air forces cooperate with each other, the more valuable experience they gain and they are also able to develop these relations and contacts on a multinational level. For example, another training project was initiated in 2013 which originated from CBT. The Arctic Challenge Exercise (ACE) takes place every second year rotating between the Norwegian Bodø, Swedish Luleå and Finnish Rovaniemi air bases (Järvenpää 2017, p. 8). However, the training is being organised on a much larger scale than CBT as it involves NORDEFCO states as well as countries from outside of that structure. For example, the 2017 edition of the ACE was one of the largest of its kind in Europe gathering over 100 different types of aircraft from 11 countries. ${ }^{19}$ The exercise involves multi-role fighters, AT and AAR aircraft, airborne early warning 
aircraft as well as transport and search and rescue helicopters and due to its size and versatility the training is now aspiring to become a Northern Flag Exercise (Ilmavoimat 2017; MoD Denmark 2016, p. 7).

Other examples of multinational training initiatives pursued within the EU framework are European Air Transport Training - EATT (recently renamed European Tactical Airlift Programme - Training: ETAP-T), and European Advanced Airlift Tactics Training Course - EAATTC. These two projects are two out of the four main deliverables of the EATF - the European Air Transport Fleet partnership, which is aiming to create an interoperable and cost-effective network of European air transport. ${ }^{20}$ EATT and EAATTC were established respectively in 2012 and 2014 with the latter being a European alternative for a similar project organised by the US Air Force - the American Advanced Airlift Tactics Training Centre. Both programmes are focused on increasing interoperability between the participating states' airlift aircraft and take place either annually - EATT, or several times a year - EAATTC (Zieliński 2013, p. 99). In addition, the EAATTC also improves the participants' knowledge of flying tactics and procedures and provides them with an academic knowledge on the subject (JAPCC 2016, p. 5). In comparison to the Arctic Challenge Exercise, the EATF projects are much more comprehensive. For example, the 2017 edition of EATT gathered 600 military personnel from seven countries ${ }^{21}$ and involved such operations as air transport, airlift, air logistic support, airborne operations, airdrops (cargo and paratroopers), aeromedical operations, non-combatant evacuation as well as the support of special operations forces (EDA 2017b). Having said that, both initiatives are important tools for building and strengthening the airlift capability through collective training. Also, as arrangements specially designed for states to learn from each other, both EATT and EAATTC are a perfect solution to allow small air forces to draw from the rich experience of their 
colleagues. Therefore, it is hardly surprising that both Poland and Sweden are involved in EATT. Poland participated in the training in 2015 (as an observer nation), 2016, 2017 and 2018, while the Swedish Air Force took part in the 2013, 2014 (under observer status) and 2015 edition (EATC 2016; EATC 2018; EDA 2013, 2014, 2015 and 2017b). The Polish Air Force has also been involved in the EAATTC twice, in 2016 and 2017 (EDA 2016 and EDA 2017a).

The above sections explored the concept of transnationalisation of small European air forces from the perspective of their participation in multinational collaborative initiatives. It demonstrated that involvement in such programmes opens up access to capabilities which otherwise could not be easily built and significantly reduces the costs of acquiring and maintaining particular types of aircraft. Nevertheless, participation in these initiatives does not come free. Small European air forces, as much as they share the resources, they also must share the costs. Together with other members of the particular initiatives they contribute financially to acquiring and maintaining the fleet they are using as well as the bases where the aircraft are located and serviced. The shared burden does not only involve money but also contributing the necessary manpower for the initiatives to be fully operational. Poland, for example, together with other NAEW members, provides the personnel for the Geilenkirchen base and fills over 20 available positions with Polish Air Force officers (Wróbel 2016).

The extent of members' contribution determines the extent to which they may use an initiative for their own purposes. The available flying hours are often divided in accordance with the nations' individual input. For example, the total annual number of flying hours available through SAC to all of its members is 3,165 (SACc). Poland is entitled to only $4.7 \%$ of that and Sweden to $17.4 \%$ (SACc). That means that both countries can use, respectively, 148.8 and 550.7 flying hours a year. Interestingly, the Swedish 
share in SAC comes second after the US (equalling 32\%), which demonstrates the extent of Sweden's contribution to the common effort (Bydén 2014, p. 172).

\section{Conclusion}

The article was aimed at answering the question of how multinational cooperation affects operational capabilities of small European air forces. It explored the subject from a perspective of the Polish and Swedish Air Forces focusing on their post-Cold War transformation which followed two major trends, namely concentration and transnationalisation. That resulted in both Air Forces becoming modernised and professionalised but also much smaller than before 1990 and, what follows, demonstrating less operational capability. Their active involvement in various forms of multinational cooperation provides evidence of increasing transnationalisation of European air forces. Answering the main research question, the article reached a two-fold conclusion.

Firstly, considering the major limitations of European air power, multinational initiatives like those discussed in the article provide access to capabilities that a small air force could not otherwise afford on their own. Therefore, they are cost-effective. Of course, participation is not cost free but it is still cheaper than building a specific capability from scratch within one's national capacity. Such a solution is greatly welcomed by not only small air forces but also the wider military sphere given the current tendency for states to decrease their military expenditure and the downsizing of military forces.

Secondly, it is not only resources such as number of aircraft which the small European air forces get access to. Extensive training programmes are also offered due to the increased transnationalisation of European militaries and their participation in 
different forms of multinational initiatives. The personnel sent to these missions or exercises gain invaluable opportunities to learn from each other. Often, they train for different capabilities and not necessarily those available back home. As a result, the aircrews come back with experience that they would not have been able to acquire otherwise. Besides, active involvement in various multinational initiatives may certainly improve the cooperation itself (Elron et al. 1999, pp. 87-88). The more frequently different air forces work together the better the opportunity to gain further understanding of each other's values, experiences and practices. As a result, it may get easier to overcome the problem of cultural diversity and anticipate potential challenges that may arise in the course of multinational cooperation.

The scope of this article did not allow for investigating in depth potential challenges that may arise from increased cooperation between European air forces. Nevertheless, it allowed to identify one particular risk that reliance on the collective capabilities may bring for small European air forces. Increased involvement in various multinational initiatives increases interdependence between participating air forces. Success of these initiatives depends heavily on the willingness of the member states to contribute to the collective effort. Vivid example of how the cooperation may be hindered is the SALIS initiative currently facing serious difficulties in access to required number of aircraft because of the withdrawal of the Russian provider. Another example may be the case of Poland withdrawing their participation from AGS when their aspirations were not met. That only shows the increased transnationalisation of European air forces may become problematic at some point and smooth cooperation may get disrupted by states' attempts to reach their own political goals while being involve in common effort. Nevertheless, for small air forces lacking operational capability as well as capacity, it is often the best way forward to make up for these shortcomings. 


\section{Notes}

1. These were: F21 Air Wing Luleå, F4 Air Wing Ostersund, F13 Air Wing Norrköping, F13M Air Wing Malmslätt, F16 Air Wing Uppsala, F10 Air Wing Angelholm, F17 Air Wing Ronneby, F6 Air Wing Karlsborg, F7 Air Wing Såtenäs, F15 Air Wing Söderhamn, F5 Air Wing Combat Flying School Ljungbyhed, F14 Air Wing Halmstad and F20 Air Wing Uppsala - Air Force Academy. See Bitzinger 1991, pp. 11-14.

2. These are now: F7 Skaraborgs in Såtenäs, F17 Blekinge in Ronneby, F21 Norrbottens in Luleå and the Helicopter Wing. See Försvarsmakten, Flygvapnet.

3. Interview with a scholar at the Swedish Defence University, Stockholm, 14 June 2016.

4. Interview with Fredrik Lindvall at the Swedish Defence Research Agency FOI, Stockholm, 13 June 2016.

5. Interview with Lieutenant Colonel Stefan Wilson, a scholar at the Swedish Defence University, Stockholm, 17 June 2016.

6. Public support for re-introducing conscription in Sweden increased from $40 \%$ in 2013 to $62 \%$ in 2016. See Berndtsson, Bjereld and Ydén, 2017.

7. Interview with Colonel in the Polish Air Force and a scholar at the National Defence University, Warsaw, 30 June 2016.

8. Full list of AGS members includes Bulgaria, Czech Republic, Denmark, Estonia, Germany, Italy, Latvia, Lithuania, Luxembourg, Norway, Poland, Romania, Slovakia, Slovenia and the US.

9. Interview with Colonel in the Polish Air Force and a scholar at the National Defence University, Warsaw, 22 June 2016.

10. The 17 NATO members at the Geilenkirchen air base are: Belgium, Canada, the Czech Republic, Denmark, Germany, Greece, Hungary, Italy, Luxembourg, the Netherlands, Norway, Poland, Portugal, Romania, Spain, Turkey and the US.

11. The 12 SAC members are: Bulgaria, Estonia, Finland, Hungary, Lithuania, the Netherlands, Norway, Poland, Romania, Slovenia, Sweden and the US.

12. The 14 SALIS members include: Belgium, the Czech Republic, Finland, France, Germany, Greece, Hungary, Luxembourg, Norway, Poland, Slovakia, Slovenia, Sweden and the UK.

13. Interview with Colonel in the Polish Air Force and a scholar at the National Defence University, Warsaw, 22 June 2016.

14. The full list of MCCE members involves 28 nations, namely Austria, Belgium, Bulgaria, Canada, Croatia, Czech Republic, Denmark, Estonia, Finland, France, Germany, Hungary, Italy, Latvia, Lithuania, Luxembourg, the Netherlands, Norway, Poland, Portugal, Romania, Slovakia, Slovenia, Spain, Sweden, Turkey, the UK and the US. 
15. Also any other type of aircraft which the ATARES nations have in their inventories may be used once its equivalent factor is calculated using the cost of one EFH.

16. Interview with Colonel in the Polish Air Force and a scholar at the National Defence University, Warsaw, 30 June 2016.

17. Interview with Fredrik Lindvall at the Swedish Defence Research Agency FOI, Stockholm, 13 June 2016.

18. Interview with Lieutenant Colonel Stefan Wilson, a scholar at the Swedish Defence University, Stockholm, 17 June 2016.

19. Among the participants of ACE 2017 were Belgium, Canada, Finland, France, Germany, the Netherlands, Norway, Sweden, Switzerland, the UK and the US.

20. The other two deliverables of EATF are the European Air Transport Symposium and the European Advanced Tactical Instructor Course.

The EATF partnership started in 2009 and is currently gathering 21 countries, such as Austria, Belgium, Bulgaria, Czech Republic, Finland, France, Germany, Greece, Hungary, Italy, Lithuania, Luxembourg, the Netherlands, Norway, Poland, Portugal, Slovakia, Slovenia, Romania, Spain and Sweden. In 2016, 11 of these nations signed a Technical Arrangement establishing European Tactical Airlift Centre - a permanent training centre based in Zaragoza in Spain.

21. The list of EATT17 participants included France, Germany, the Netherlands, Poland, Portugal, Romania and the UK.

\section{References}

1990. The Alliances and Europe. The Military Balance, 90 (1), 44-96.

1995a. NATO. The Military Balance, 95 (1), 33-67.

1995b. Non-NATO Europe. The Military Balance, 95 (1), 68-101.

2000. NATO and Non-NATO Europe. The Military Balance, 100 (1), 35-108.

2005a. Europe. The Military Balance, 105 (1), 45-106.

2005b. Europe: non-NATO. The Military Balance, 105 (1), 107-150.

2010. Europe. The Military Balance, 110 (1), 103-210.

2015. Europe. The Military Balance, 115 (1), 57-158.

Air Cargo News, 2018. NATO confirms Volga-Dnepr notice to quit SALIS. [online]

Available at: https://www.aircargonews.net/news/airline/freighter- 
operator/single-view/news/nato-confirms-volga-dnepr-notice-to-quit-salis.html [accessed 08/08/2018].

Andersson, J. J., 2007. A New Swedish Defence for a Brave New World. In: J. H. Matlary and Ø. Østerud, eds. Denationalisation of Defence: Convergence and Diversity, Aldershot, Hampshire: Ashgate, 135-156.

Anrig, C. F., 2011a. Continental Europe. In: J. A. Olsen, ed. Global Air Power. Washington D.C.: Potomac Books, 373-408.

Anrig, C. F., 2011b. The Quest for Relevant Air Power: Continental European Responses to the Air Power Challenges of the Post-Cold War Era. Maxwell Air Force Base, Alabama: Air University Press.

Archer, C., 2014. The Nordic States and Security. In: C. Archer, A. J. K. Bailes and A. Wivel, eds. Small States and International Security: Europe and Beyond. London: Routledge, 95-112.

Attride-Stirling, J. 2001. Thematic networks: An analytic tool for qualitative research. Qualitative Research, 1, 385-405.

Berndtsson, J., Bjereld, U. and Ydén, K., 2017. Starkt stöd för försvaret men färre vill gå med i Nato. Dagens Nyheter [online] Available at: https://www.dn.se/debatt/starkt-stod-for-forsvaret-men-farre-vill-ga-med-i-nato/ [accessed 10/03/2017].

Bitzinger, R. A., 1991. Facing the Future. The Swedish Air Force, 1990-2005. Santa Monica: RAND.

Bydén, M., 2014. Swedish Air Power. Delivering Independently, Joint, and Combined. In: J. A. Olsen, ed. European Air Power: Challenges and Opportunities. Lincoln, Neb.: Potomac Books, 170-184. 
Ciastoń, R., et al., 2014. Sity Zbrojne RP - stan, perspektywy i wyzwania modernizacyjne. Warsaw: Fundacja im. Kazimierza Pułaskiego.

Dahl, A.-S., 2014. NORDEFCO and NATO: "Smart Defence" in the North? NATO Research Paper, no. 101.

Dyčka, L. and Mareš, M., 2012. The Development and Future of Fighter Planes Acquisitions in Countries of the Visegrad Group. The Journal of Slavic Military Studies, 25(4), 533-557.

EATC, 2016. European Air Transport Training (EATT) 2016. [online] Available from: http://eatcmil.com/45/News/EATT15/366/European+Air+Transport+Training+\%28EATT \%29+2016 [accessed 03/03/2017].

EATC, 2018. ETAP-T 2018 another successful example recognising EATC as a centre of expertise in air transport! [online] Available at: https://eatcmil.com/post/etap-t-2018-another-successful-example-recognising-eatc-as-acentre-of-expertise-in-air-transport [accessed 08/08/2018].

EDA, 2017a. EAATTC 17-3. [online] Available from:

https://www.eda.europa.eu/docs/default-source/eda-factsheets/eaattc173_factsheet_v3 [accessed 11/09/2017].

EDA, 2017b. EATT17 closes with advanced tactical airlift operations. [online]

Available from: https://eda.europa.eu/info-hub/press-centre/latestnews/2017/06/29/eatt17-closes-with-advanced-tactical-airlift-operations [accessed 11/09/2017].

EDA, 2016. EAATTC 16-1. [online] Available from: https://www.eda.europa.eu/docs/default-source/eda-factsheets/eaattc-161_factsheet [accessed 11/09/2017]. 
EDA, 2015. EATT 15. [online] Available from: https://www.eda.europa.eu/docs/defaultsource/eda-factsheets/eatt-15-factsheet [accessed 11/09/2017].

EDA, 2014. European Air Transport Training 2014. [online] Available from:

https://www.eda.europa.eu/docs/default-source/eda-factsheets/2014-06-16factsheet_eatt14_high [accessed 11/09/2017].

EDA, 2013. European Air Transport Training 2013 (EATT13). [online] Available from: https://www.eda.europa.eu/docs/default-source/eda-factsheets/eattfactsheet_10062013_cs5_bleu [accessed 11/09/2017].

Elron, E., Shamir, B. and Ben-Ari, E., 1999. Why Don't They Fight Each Other? Cultural Diversity and Operational Unity in Multinational Forces. Armed Forces and Society, 26(1), 73-98.

Flight International, 2017. World Air Forces 2017. Insight from Flight Global. [online] Available from: https://www.flightglobal.com/news/articles/insight-fromflightglobal-world-air-forces-on-the-r-432247/ [accessed 05/12/2017].

Försvarsmakten. Flygvapnet. Available from: http://www.forsvarsmakten.se/sv/varverksamhet/verksamhetsomraden/flygvapnet/ [accessed 20/07/2017].

Government Offices of Sweden, 2017. Sweden re-activates conscription. [online] Available at: http://www.government.se/articles/2017/03/re-activation-ofenrolment-and-the-conscription/ [accessed 10/07/2017].

Górka, M., 2016. Działa już pierwsza baza bezzałogowców. Polska Zbrojna [online] Available from: http://www.polskazbrojna.pl/home/articleshow/18154?t=Dziala-juz-pierwsza-bazabezzalogowcow [accessed 20/07/2017].

Haltiner, K. W., 2006. The Decline of the European Mass Armies. In: G. Caforio, ed. Handbook of the Sociology of the Military. Boston, MA: Springer, 361-384. 
Hayward, J., ed., 2009. Air Power, Insurgency and the "War on Terror”. Cranwell: Royal Air Force Centre for Air Power Studies.

Hofstede, Geert. Culture's Consequences: Comparing Values, Behaviours, Institutions and Organisations across Nations. Second Edition. London: Sage, 2001.

Hołdanowicz, G., 2009 Nieprimaaprilisowe pożegnanie z AGS. Raport - Wojsko Technika Obronność [online] Available from: http://www.altair.com.pl/magazines/article?article_id=2214 [accessed 29/08/2017].

Ilmavoimat, 2017. Flight Detachments and Air Bases in Arctic Challenge Exercise 17. [online] Available from: http://ilmavoimat.fi/en/article/-/asset_publisher/arcticchallenge-exercise-17-lentotoimintaharjoituksen-lentavat-joukot-ja-tukikohdat [accessed 20/09/2017].

JAPCC, 2016. NATO/EU Air Transport Training Exercises and Interoperability. Kalkar: Joint Air Power Competence Centre.

Järvenpää, P. 2017. NORDEFCO: „Love in a Cold Climate”? Tallin: International Centre for Defence and Security.

Kainikara, S., 2011. At the Critical Juncture. The Predicament of Small Air Force. Canberra: Air Power Development Centre.

King, A., 2005. Towards a Transnational Europe: The Case of the Armed Forces. European Journal of Social Theory, 8(3), 321-340.

King, A., 2011. The Transformation of Europe's Armed Forces. From the Rhine to Afghanistan. Cambridge: Cambridge University Press.

King, N. 2004. Using templates in the thematic analysis of text. In: C. Cassell and G. Symon, eds. Essential guide to qualitative methods in organizational research. London: Sage, 257-270. 
Lambeth, B. S., 2000. The Transformation of American Air Power. Ithaca; London: Cornell University Press.

Lambeth, B. S., 2005. Air Power against Terror: America's Conduct of Operation Enduring Freedom. Santa Monica: RAND.

Łastawski, K., 2011. Sytuacja geopolityczna Polski po przemianach ustrojowych i wstąpieniu do Unii Europejskiej. Studia Europejskie, 1, 19-40.

Mackenzie, S. A., 1994. Strategic Air Power Doctrine for Small Air Forces. Canberra: Air Power Studies Centre.

MCCE. Air Transport. [online] Available from: http://mcce-mil.com/air-transport/ [accessed 14/03/2017].

MCCE, 2017. MCCE support to Arctic Challenge 2017. [online] Available from: http://mcce-mil.com/2017/05/mcce-support-to-arctic-challenge-2017/ [accessed 31/08/2017].

Ministry of National Defence Republic of Poland, 2016. AWACS over NATO's Eastern Flank. [online]. Available from: http://en.mon.gov.pl/news/article/latestnews/awacs-over-natos-eastern-flank-22016-10-14/ [accessed 30/08/2017].

Ministry of Defence of Denmark, 2016. NORDEFCO Annual Report 2016.

Müller, B., 2017. Battle for Strategic Airlift Interim Solution. [online] Available from: https://www.offiziere.ch/?p=27319 [accessed 31/08/2017].

NAPMA. NAEW\&C Force. [online]. Available from: http://www.napma.nato.int/organisation/5.html [accessed 10/03/2017].

NATO, 2018. Alliance Ground Surveillance (AGS). [online]. Available from: http://www.nato.int/cps/en/natohq/topics_48892.htm [accessed 08/08/2018].

NATO, 2015. Strategic Airlift Interim Solution (SALIS). [online] Available from: http://www.nato.int/cps/en/natohq/topics_50106.htm [accessed 10/03/2017]. 
NATO Standardisation Agency, 2014. NATO Glossary of Terms and Definitions AAP06 (English and French).

Nowell, L. S., et al., Thematic Analysis: Striving to Meet the Trustworthiness Criteria. International Journal of Qualitative Methods, 16, 1-13.

Olsen, J. A., ed., 2011. Global Air Power. Washington D.C.: Potomac Books.

Olsen, J. A., ed., 2014. European Air Power: Challenges and Opportunities. Lincoln, Neb.: Potomac Books.

Olsen, J. A., ed., 2017. Airpower applied: U.S., NATO, and Israeli combat experience. Annapolis, MD: Naval Institute Press.

Oltermann, P., 2017. Sweden to reintroduce conscription amid rising Baltic tensions. The Guardian [online] Available at: https://www.theguardian.com/world/2017/mar/02/sweden-reintroduceconscription-amid-rising-baltic-tensions [accessed 07/11/2017].

Petersson, M., 2011. Defense Transformation and Legitimacy in Scandinavia after the Cold War: Teoretical and Practical Implications. Armed Forces \& Society, 37(4), 701-724.

PZL Mielec, 2009. Products. [online] Available from: http://www.pzlmielec.pl/en/offer/products/ [accessed 10/11/2017].

PZL Świdnik, 2010. Products. [online] Available from: http://www.pzl.swidnik.pl/en/product/catalogmodule/en/military-government/0,2,14/ [accessed 10/11/2017].

Quintana, E., Heidenkamp, H. and Codner, M., 2014. Europe's Air Transport and Airto-Air Refuelling Capability: Examining the Collaborative Imperative. RUSI Occasional Paper. Available from: https://rusi.org/publication/occasional- 
papers/europes-air-transport-and-air-air-refuelling-capability-examining [accessed 27/03/2017].

Saab. Airborne Solutions. [online] Available from: https://saab.com/air/\#airbornesolutions [accessed 10/11/2017].

Sabak, J., 2017. Rosyjskie An-124 nadal wożą sprzęt NATO. Defence 24 [online] Available from: http://www.defence24.pl/525862,rosyjskie-an-124-nadal-wozasprzet-nato [accessed 31/08/2017].

SACa. Heavy Airlift Wing. [online] Available from: https://www.sacprogram.org/en/Pages/Heavy-Airlift-Wing.aspx [accessed 31/08/2017].

SACb. SAC Milestones 2006 -. [online] Available from: https://www.sacprogram.org/en/Pages/SAC-Milestones-2006-.aspx [accessed 31/08/2017].

SACc. The Strategic Airlift Capability (SAC). [online] Available from: https://www.sacprogram.org/en/Pages/The\%20Strategic\%20Airlift\%20Capabilit y.aspx [accessed 31/08/2017].

Seguin, B. R., 2007. Why did Poland choose the F-16? The Marshall Center Occasional Paper Series. Garmisch-Partenkirchen: The George C. Marshall European Center for Security Studies.

SIPRI, 2018. Military Expenditure Database. [online] Available from: http://sipri.org/databases/milex [accessed 21/05/2018].

Soeters, J. L., 1997. Value Orientations in Military Academies: A Thirteen Country Study. Armed Forces \& Society, 24(1), 7-32.

Soeters, J. L., Hofstede, G. and Van Twuyver, M., 1995. Culture's consequences and the police: Cross-border cooperation between police forces in Germany, Belgium 
and the Netherlands. Policing and Society: An International Journal of Research and Policy, 5(1), 1-14.

Stephens, A., 1999. High Noon of Air Power. Paper No. 71, Canberra: Air Power Studies Centre.

Średnicki, Z., 2015. Modernizacja techniczna sił powietrznych. Przegląd Sił Zbrojnych, $3,8-15$

van Creveld, M., 2011. The Age of Airpower. New York: PublicAffairs.

Wróbel, T., 2016. Tysiąc lotów AWACS-a nad Polską. Polska Zbrojna [online]. Available from: http://polska-zbrojna.pl/home/articleshow/20759?t=Tysiaclotow-AWACS-a-nad-Polska [accessed 30/08/2017].

Zieliński, T., 2013. Overview of Allied Defence Capabilities in the Area of Aviation within the Context of the Smart Defence Initiative. NDU Scientific Quarterly, 90(1), 93-106. 


\section{Figures:}

Figure 1. Number and type of aircraft in the Polish and Swedish Air Force.

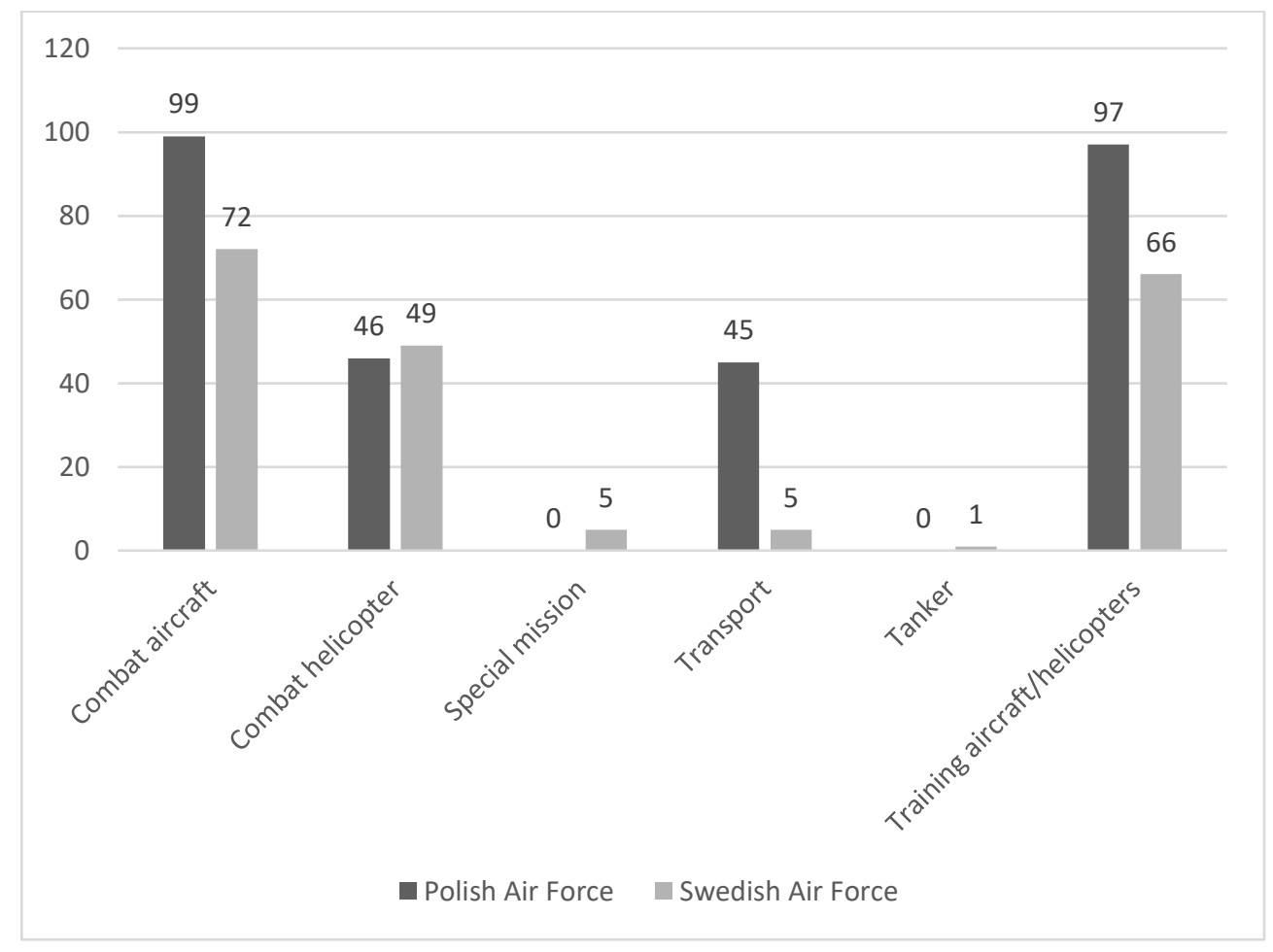

Source: Flight International, 2017. World Air Forces 2017. Insight from Flight Global.

Available at: <https://www.flightglobal.com/news/articles/insight-from-flightglobalworld-air-forces-on-the-r-432247/> [accessed 05/12/2017], pp. 14-15. 
Figure 2. Total armed forces personnel in Poland and Sweden, 1990-2015.

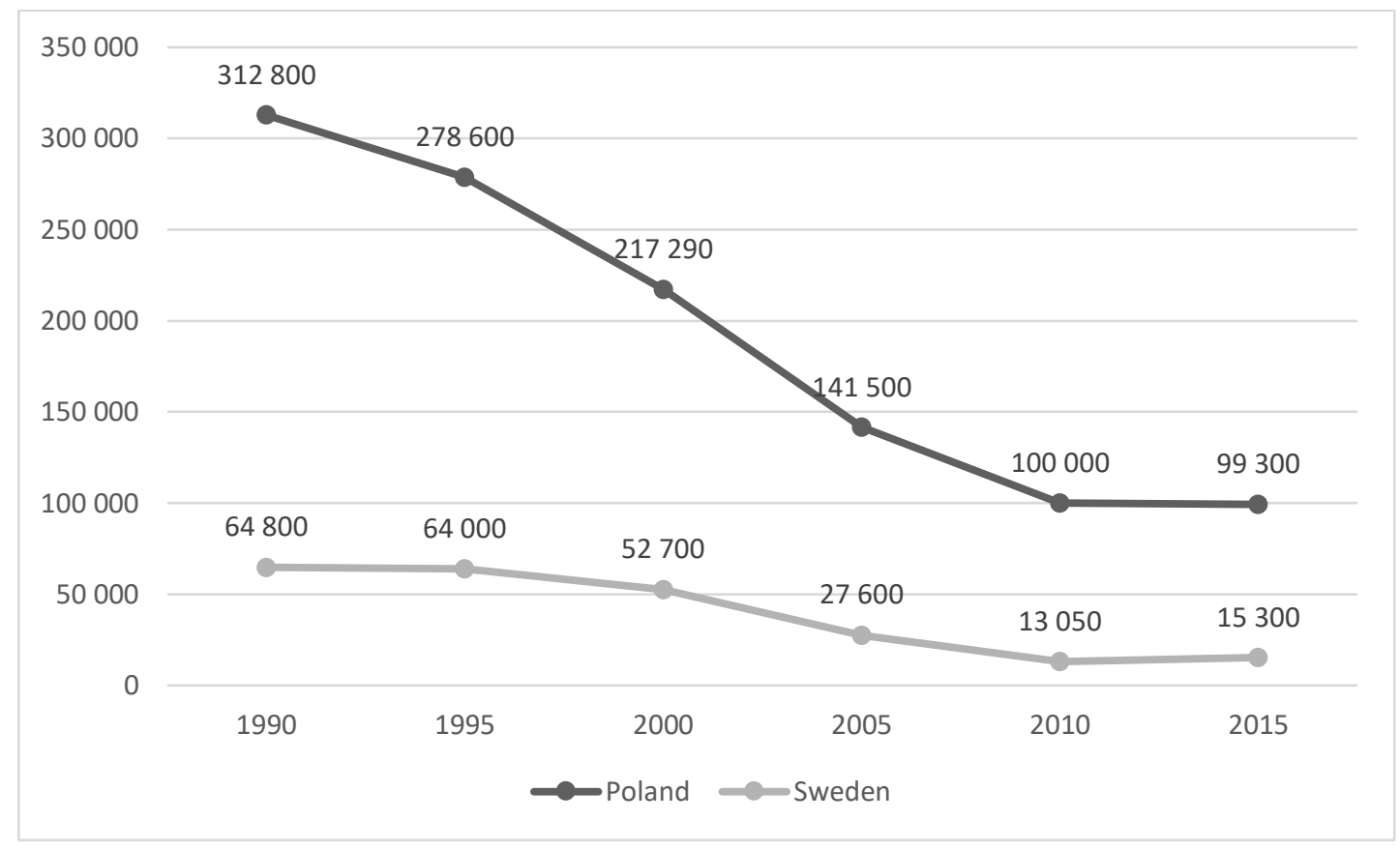

Sources: 1990. The Alliances and Europe. The Military Balance, 90 (1), 44-96; 1995a. NATO. The Military Balance, 95 (1), 33-67; 1995b. Non-NATO Europe. The Military Balance, 95 (1), 68-101.; 2000. NATO and Non-NATO Europe. The Military Balance, 100 (1), 35-108; 2005a. Europe. The Military Balance, 105 (1), 45-106; 2005b. Europe: non-NATO. The Military Balance, 105 (1), 107-150; 2010. Europe. The Military Balance, 110 (1), 103-210; 2015. Europe. The Military Balance, 115 (1), 57-158. 
Figure 3. Total air forces personnel in Poland and Sweden, 1990-2015.

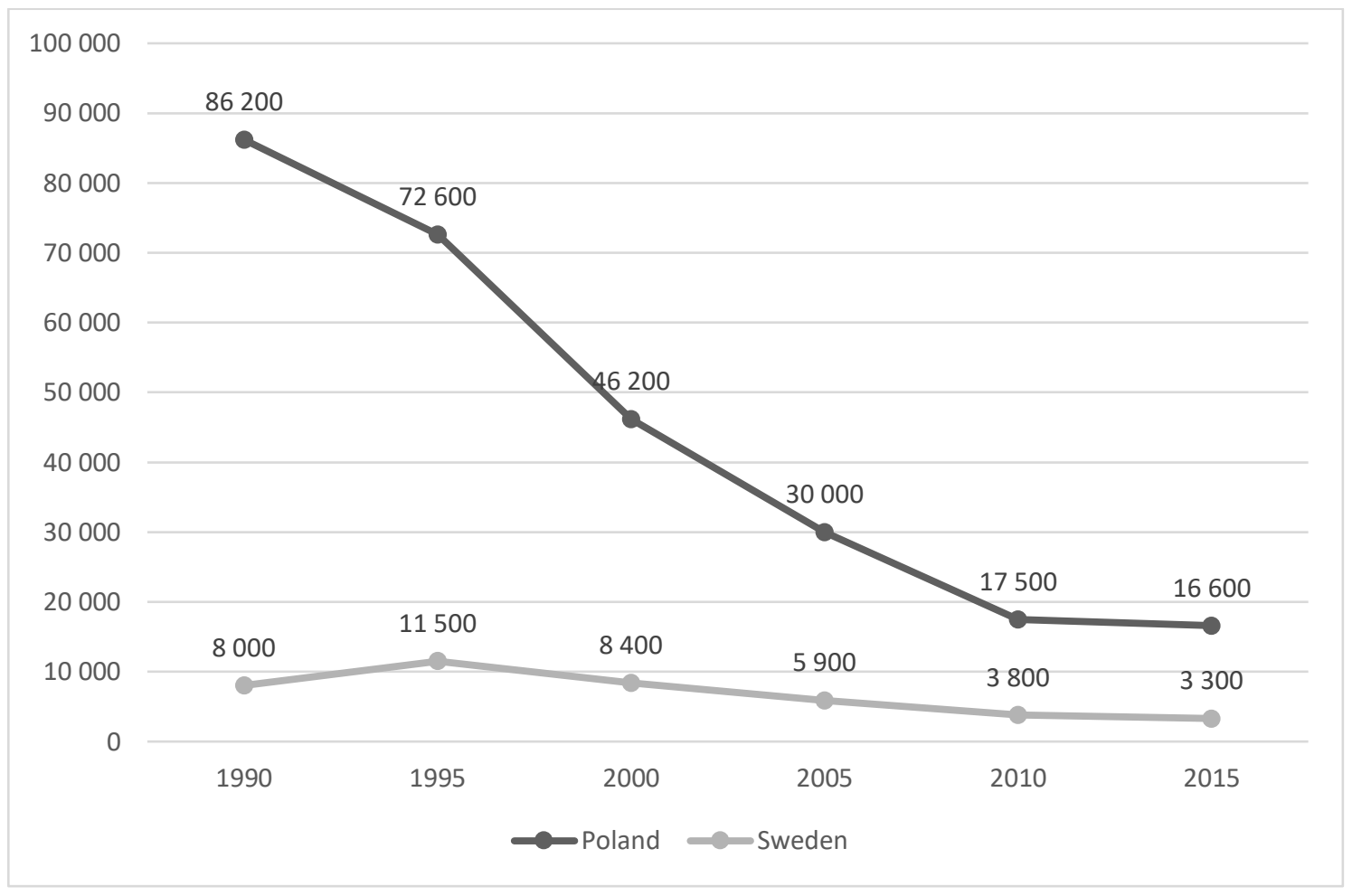

Sources: 1990. The Alliances and Europe. The Military Balance, 90 (1), 44-96; 1995a. NATO. The Military Balance, 95 (1), 33-67; 1995b. Non-NATO Europe. The Military Balance, 95 (1), 68-101.; 2000. NATO and Non-NATO Europe. The Military Balance, 100 (1), 35-108; 2005a. Europe. The Military Balance, 105 (1), 45-106; 2005b. Europe: non-NATO. The Military Balance, 105 (1), 107-150; 2010. Europe. The Military Balance, 110 (1), 103-210; 2015. Europe. The Military Balance, 115 (1), 57-158. 